\title{
THE CURRENT STATE AND PROBLEMS IN PERFORMING PREVENTION OF SOCIO-PATHOLOGICAL PHENOMENA IN SCHOOLS IN SLOVAKIA
}

\author{
Ingrid Emmerová
}

\begin{abstract}
An increase in problem behaviour of varying intensity with pupils of primary and secondary schools raises the necessity of performing effective prevention. This paper approximates the current state of its implementation and analyzes the problems which it encounters in the conditions of Slovak schools. It also presents the current situation of the occurrence of problematic and risk behaviour among pupils at primary and secondary schools.
\end{abstract}

\section{Keywords}

prevention, educational prevention, problem and risk behaviour of pupils

Teachers of primary and secondary schools often, many of them daily, encounter inappropriate behaviour of their pupils. The spectrum of such behaviour is broad: from minor violations of the Rules of Order to serious socio-pathological phenomena, which from the point of view of preventive activity and subsequent solutions is important to distinguish.

Socio-pathological phenomena are unhealthy, abnormal and adverse social phenomena. Currently, the group of socio-pathological phenomena includes particularly: crime and delinquency, pathological addiction (drugs, cults, gaming, ...), suicide rates, prostitution and venereal diseases, pathology of the family (CAN syndrome, family violence, ...), xenophobia and racism, aggression and bullying. Behavioural disorders are marked by conduct different from normal behaviour which elicits objections on the part of the society and causes behavioural problems. Their influence on the surroundings is disturbing and causes a hindered social adaptation in children and the youth. From a pedagogical point of view, we understand behavioural disturbances as a "wide, etiologically diverse spectrum of maladaptive behaviour, wherein the individual is resistant to conventional educational activity and it is a matter of a permanent characteristic trait and personality expression". (Levčíková, M. et al., 2004, p. 4) Behavioural disorders are manifested through disrespect and violations of rules, disciplinary problems etc., they represent a wide variety of violations of moral standards and of the age-adequate social expectations that lead to violent behaviour. Behavioural disorders complicate the teaching process, as the behaviour of such a pupil does not comply with the Rules of Order. 
Behavioural disorders are understood as deviations appearing in the realm of the socialization of the individual who is unable to respect and internalize the standards of behaviour adequate to their age and intellect.

V. Labáth (2011, p. 11) analyzes the term "the risk youth", which, according to him denotes adolescents who are due to the influence of multiple factors more likely to fail in social and psychic realms. This understanding may mean "dangerous youth", but also the youth who have problems with social adaptation, and conversely, can be understood in the sense of the endangered children and youth, these can be children and youth who come from socially disadvantageous environment. M. Zelina (2011, pp. 4-5) proposes to divide inappropriate behaviour of children as follows:

1. Undisciplined behaviour (asocial): It occurs episodically and has no negative social charge. Undisciplined behaviour breaches school standards and precepts, disturbing in classes, copying assignments, using vulgar language and the like are typical of this. This kind of behaviour is solved by the parents, teachers, educators, and may be treated through a warning or counselling. From the point of view of prevention at schools and school facilities, it is possible to define two more categories which lead to inappropriate behaviour.

a) Risk behaviour: Risk individuals have a high likelihood of occurrence of problematic behaviour (e.g. risk families).

b) Onlooker behaviour: It is characterized by the pupil's being disengaged in social affairs, being disinterested in what people around him/her do, not protesting against evil, not reporting bullying and having no motivation to engage.

2. Problem behaviour (asocial): This includes also violations of standards and rules which have a lasting and intense character, are serious and repeated. Individuals in this category require constant counselling work. Problem behaviour more often requires the removal of the person from their natural environment and there is also an effort to change the social conditions of the person of problem behaviour.

3. Behavioural disorders (anti-social): Anti-social behaviour represents the highest and most severe degree of manifestations of inappropriate behaviour. It concerns individuals with aggressive behaviour, persons who have committed crimes, etc. Anti-social behaviour may be aimed against people, property and oneself.

The difference between the terms behavioural disorder and problem behaviour is pointed out by Š. Vašek (1995, p. 116) according to whom problem behaviour forms the first phase of the development of the actual behavioural disorder - the non-adaptive form of behaviour of individuals or small groups which have an indirect effect on the social relational framework, the socialization process of an individual, or the functioning of the group, and which disturb the ethical, legal and other social standards. Unless these standards are breached (they only are not accepted), it is more appropriate to talk about problem behaviour.

\section{The Current Status of the Problem and Risk Behaviour of Primary and Secondary School Pupils}

The current occurrence of problem and risk behaviour in children and the youth may be presented based on the results of objective research. 
The international study OECD TALIS (2008) presents data on the negative behaviour of pupils. The situation in Slovakia is better than the international average of the countries involved only in the regular encounter of teachers with the pupils' late-coming $(39.4 \%$ is the international average and the situation in Slovakia is $13 \%$ ) and pupils' absences (45.8 \% international average and situation in Slovakia is $39.8 \%$ ). The situation is different with the behaviour of the pupils who do come to school: the pupils' disturbing during teaching (international average $60.2 \%$, Slovakia $71.6 \%$ ), lying and cheating (20.9\% international average, Slovakia $38.5 \%$ ), damages to school property (international average $27.1 \%$, Slovakia $32.3 \%$ ). In all these parametres, the situation in Slovakia is worse than the international average.

In September and October 2010, we carried out a research using the questionnaire method on teachers at primary and secondary schools in the Central Slovak region (the sample is applicable to the Slovak Republic). The research sample consisted of 196 teachers of primary and 155 teachers of secondary schools, 351 respondents in total. On the whole, we may state that the most wide-spread problem behaviour of pupils is truancy, which was mentioned by $84.05 \%$ of the respondents. Next, aggressive behaviour (80.91\%), bullying (60.97\%) and legal drug use (50.99\% of all respondents). Aggressive behaviour is the most wide-spread behaviour at primary schools this option was marked by $83.16 \%$ of primary schools, the most wide-spread problem at secondary schools is truancy. Thefts pose a greater problem in primary school pupils (52.04\%) than experiments with legal drugs (47.96\%). A considerable percentage difference between the answers of the respondents - teachers from primary and from secondary schools - was recorded with illicit drug abuse (13.27\% vs. $43.87 \%)$.

The respondents - teachers of primary and secondary schools - encounter the problem behaviour of pupils in a great extent, and utterly dangerous socio-pathological phenomena are not rare. Only $1.71 \%$ of the respondents ( $2.04 \%$ from primary and $1.29 \%$ from secondary schools) have not encountered problem behaviour in their pupils. This fact once again confirms the pressing nature of this problem and the inevitability of effective and systematic prevention as well as solutions to the risen problem.

The current situation in schooling is also described by the Report on the State of the School System in the Slovak Republic and on Systemic Steps to Support the Further Development of September 2013, which states:

-A significant problem for the school system is the endangerment of the pupils, the pedagogues and the non-pedagogical staff (bullying of the pupils, attacks on teachers by the pupils, or by their legal representatives).

- Schools do not have at their disposal any tools to increase the security of the pupils or of the staff.

- The school staff point out their insufficient education and practical training in solving urgent crisis situations, despite the fact that the Act on Pedagogical and Professional Staff does not raise this requirement.

- With reference to the National Drug Monitoring Centres, alcohol and drugs are growing in abuse with pupils of lower age cohorts.

The inevitability of systematic and effective prevention already with pupils of the first stage primary schools is also attested to by the results of a screening test which was carried out in 2013. The teachers of all Slovak regions, (except for Region Bratislava), have listed pupils whom they recommend into the care of pedagogical counselling and drug prevention facilities, as they could not solve 
their behaviour their problem directly at school. Based on the results of the most significant nature, we may state that (2014, p. 81):

- the teachers of the examined schools recommended $18.10 \%$ pupils to the pedagogical care,

- all the manifestations of problem behaviour (including truancy, contact with addictive substances, criminal activity) do not only involve the second stage primary pupils, but compared to the past, a steep increase of problem behaviour of first stage primary pupils has been recorded, - compared to the previous time periods, there is a significant increase of the number of problem girls. A frequently used punishment for problem behaviour in primary and secondary schools is the lowered grade in behaviour. According to the research findings of M. Pétiová et al. (2014, with 15-17), the most frequent reasons for the lowering of the grade in behaviour mentioned by the headmasters is the breach of Rules of Order, truancy, unresolved absences and inappropriate behaviour of the pupils. With secondary school headmasters, the dominant violations are truancy, breach of Rules of Order and inappropriate behaviour.

The educational problems are the subject of the meetings of the pedagogical council. According to the Report on the State of the Security in the School Environment and of the Prevention of Negative Phenomena in the Behaviour of the Pupils at Primary School in the School Year 2013/2014, at Grammar Schools in the School Year 2013/2014 and at Vocational Secondary Schools in the School Year 2013/2014 in the Slovak Republic, the most frequent educational problems which the pedagogical councils had to concern themselves with, were:

- at primary schools: inappropriate behaviour during teaching (disturbing, talking back at the teacher), disrespect to the teachers' instructions and vulgar language among the pupils,

- at grammar schools: inappropriate behaviour during teaching (disturbing, talking back at the teacher), and poor attendance of the pupils in classes,

- at vocational secondary schools: poor attendance of the pupils in classes, disrespect to the teachers' instructions, inappropriate behaviour during teaching (disturbing, talking back at the teacher), and escapism from classes.

The empirical findings of M. Pétiová (2015, pp. 11-12) attest to a poor situation which involves the relationships between the pupils and the teachers. In 2014, compared to 2005, the number of responding pupils who liked their teachers and honoured them decreased (from $17.1 \%$ to $10.0 \%$ ) and the number of pupils who do not like their teachers grew (from $6.0 \%$ to $9.2 \%$ ), or their teachers are indifferent to them (from $3.0 \%$ to $8.1 \%$ ).

The results of the researches present the reality of the school practice. Information referred to here point at the current situation in primary and secondary schools in Slovakia concerning the growth of problem behaviour of the pupils which summons the need for effective prevention and adequate solutions to the arising problems.

\section{Current State of the Prevention Carried Out at Schools in Slovakia}

The school, primary school especially, plays an important role, as it is frequented by the whole population of the age of 6, apart from individual exceptions. It is therefore inevitable to carry out primary prevention and effectively solve cases of the manifestation of problem behaviour of pupils. 
As a professional institution, a school ensures the realization of prevention, especially of the primary prevention, and if problem behaviour in pupils is wide-spread, also secondary prevention. In the field of secondary prevention, it develops complex care of the pupils with problem behaviour, from the upbringing problems in the family, over the breaching of the Rules of Order down to breaking the current legislation.

The main agents of prevention at primary and secondary schools in Slovakia are the coordinators of prevention. To the harm of the matter, i.e. to school prevention, the Act on Schooling apart from the function of the social pedagogue, only leaves the function of the prevention coordinator as an unpaid one, carried out by a pedagogical staff member - a teacher.

The director of a primary or secondary school appoints a teacher into the position of a prevention coordinator based on his/her voluntary interest, personal readiness and professional aptitude, usually for the period of one year. The prevention coordinator carries out the following tasks:

- Elaborates the plan of preventive measures for the school year in question.

- Fulfils the role of the school counselling in questions of the prevention of drug and other addictions.

- Pays special attention to the pupils from disadvantaged, socially excluded environment (endangered by social pathologies), where the risk of developing socially negative phenomena, including drug addiction, is higher.

- Secures the coordination of prevention as an integral part of the educational training process. In the framework of the school, provides preventive-educational consultations to the pupils and their legal representatives.

- Mediates the connection between the school and preventive, counselling and other professional capacities and NGOs involved in prevention.

- Coordinates and methodically delimits preventive anti-drug educational and informational activity towards the pedagogical staff at the school, observing in a long-term, systematic manner and evaluating the development of pupils endangered by drug addiction or other social pathology.

- Informs the pupils (or their legal representatives) on the activity of the preventive counselling and other professional facilities and the possibilities of drug addiction or other addictive prevention.

In the Czech Republic, a similar function is carried out by the school prevention methodologist.

The principles of effective prevention of risk behaviour in children and the youth, according to M. Miovský, J. Zapletalová, L. Skácelová (2010, p. 39-41), include:

a) Complexity and combination of numerous strategies, aimed at a certain target group. Prevention needs to be conceived as a summary of a number of factors, and as a coordinated cooperation of various institutions.

b) The continuity of work and the systematic manner of planning.

c) Adequate informative and other forms of activities aimed at the target population and its age-specific traits.

d) An early start of preventive activities, ideally already in preschool age.

e) Positive orientation of primary prevention and the demonstration of specific alternatives. The promotion of a healthy lifestyle, utilization of positive models and the offer of attractive positive alternatives.

f) The focus should not include only the level of information, but especially the quality of attitudes and the change of behaviour. The aim of prevention is to influence genuine behaviour. 
g) The utilization of peer-based elements, emphasis on interaction and active involvement. For children and adolescents, their peers may often present authority of greater influence than the parents or teacher have.

h) De-normalization - primary prevention should contribute to the creation of such social climate that is not favourable to the support of the development of risk behaviour. Changing the standards and values so that risk behaviour does not appear as beneficial, nor as a social standard.

i) Support of protective factors in the society.

j) Non-implementation of ineffective means. It has proven ineffective to simply provide health or other kinds of information on the given risk behaviour. Also inefficient are intimidations, bans, moralization or exaggeration of the consequences.

In the school year 2009/2010, the State Institute of Pedagogy of the Slovak Republic carried out a questionnaire survey entitled The Prevention in Primary School Practice in Slovakia (Bizíková, L'., 2011), which showed that the most often given long-term goal of prevention in terms of its content was primary prevention, closer specified as the effort to protect the pupils from substance abuse along with the prevention of bullying. The second most frequent long-term goal of the schools was to eliminate aggression, fight xenophobia, intolerance and bullying.

Prevention in schools is carried out in various forms of activity. The most appropriate are preventive projects or programs. "Implementing prevention of socio-pathological phenomena, we need to lay emphasis on its systematic nature. Practice shows that the regular organization of preventive activities is much more efficient than organizing a one-time event." (Kováčová, A., 2015, s. 40) Among one-time activities, the most dominant is a discussion with an expert, and professional lectures. It is recommended to include prevention of socio-pathological phenomena into the instruction of individual subjects.

Lectures are not an efficient form of prevention, and an inappropriate form for pupils of primary school, but once connected with a discussion on a given topic, they may form a supplement of the preventive work. The very wide-spread means of prevention are leaflets, competitions, quizzes, television or radio segments and also, inappropriate discussions with former substance addicts. Positive possibility to evaluate one-time activities, such as excursion to a concentration camp, excursion to re-educational centre, etc.

\section{Problems in the Implementation of School Prevention and the Possibilities of Turning It Professional}

The problems in implementing prevention in the current school practice are numerous and we may list these:

- prevention coordinators - pedagogical staff members who often are not ready for the implementation of prevention and lack the required erudition,

- the prevention coordinator at the primary school is usually from among the second stage teachers and their focus is in the age category of the second stage, the first stage of primary is not paid attention to in terms of prevention; a more positive evaluation can be given to schools where one prevention coordinator works with the first stage and another one with the second stage,

- the work of the coordinator is not reflected in their workload and they are not exempted from other duties, 
- there are schools where the teachers change year after year,

- there is no monitoring of inappropriate and problem behaviour, so prevention activities are not aimed at real risks,

- preventive activity are often unattractive to the pupil (the information is repetitive) and they often are carried out in the same monologue form without any active participation of the addressee of the monologue,

- schools often run "mass preventive events" which are organized for large groups of pupils and where they lack the opportunity to express themselves.

Many of the problems stem from the insufficient professionalization of prevention at schools in Slovakia. As P. Ondrejkovič states (2013, p. 12) "the lack of professionality which the current state is marked by results especially in low effectiveness of prevention in all of its three kinds (primary, secondary and tertiary)".

Preventive activities must consist of systematic work, implemented at the professional level. In this regard, it is necessary to specifically highlight the work of social pedagogues in schools because they have expertise to carry out primary and secondary prevention, as well as other socially educational work. Their activities at schools are already included in the legislation of the Slovak Republic. According to the Act on Education and Training, the social educator has been added to the other components of the system of educational counselling and prevention in Section 130 of the Act on Educational, Pedagogical and Professional Staff no. 317/2009 where the position is incorporated into the category of professional staff. Section 24 states: The social educator performs professional activities in the framework of prevention, intervention and counselling especially with children and pupils at risk of social pathological phenomena, from socially disadvantaged backgrounds, drug addicts or otherwise disadvantaged children and to pupils, their legal representatives and teaching staff of schools and educational establishments. The social educator fulfils the tasks of social education, support of pro-social, ethical conduct, socio-pedagogical diagnostics of the environment and relationships, socio-pedagogical counselling, prevention of socio-pathological phenomena and re-education of behaviour. S/he performs expert activities and educational activities.

The implementation of prevention of socio-pathological phenomena can be considered as a dominant sphere of interest, as well as specific activities of the social pedagogue at the school. Currently, at schools in the Slovak Republic, the core responsibility for the implementation of prevention rests on the shoulders of the prevention coordinators - teachers who are mostly in full-time teaching employment and not financially remunerated for the performance of this position, often even not possessing the required qualification. The rise of socio-pathological phenomena in children and the youth, however, requires professionalization of prevention already in school environments, where social pedagogues should operate who would have the professional training.

The efficient and effective primary prevention includes continuous and comprehensive programs, interactive programs, especially programs assisting the pupils to confront social pressure aimed at improving communication, non-violent management of conflicts, rejection of addictive substances, raising healthy self-esteem, coping with anxiety and stress. It is important to carry out various cooperative activities.

E. Smiková (2012) divides prevention programs (with particular regard to drug prevention programs) into programs aimed at the elucidation of information (emphasis is placed on knowledge and understanding), programs focused on emotional learning and education (e.g. training of 
decision-making skills, elucidation of values, stress management and raising self-esteem), programs focused on social influence (informing the pupils about peer pressure and other social pressures and developing skills to withstand pressure), or general programs, i.e. complex ones (includes information, training of skills, decision-making and resisting, components of creating commitments and standards), alternative programs (these programs emphasize the training of living skills and the provision of alternatives, e.g. in case of drug abuse).

The ineffective prevention includes intimidation, emotional appeals, simple information hand-over, one-time events, mass activities of film screenings without being followed by a discussion or conversation in small groups.

Another area of a social pedagogue's performance is the solving of the problem of behaviour of pupils - in primary and secondary school pupils, this includes a broad spectrum of inappropriate, problem behaviour that still may not fall into the group of behavioural disorders or socio-pathological phenomena. These include: stealing, destroying property and vandalism, delinquent behaviour (when a pupil comes into conflict with the law), aggression and bullying, truancy, running away and vagrancy, lying and cheating, use of licit or illicit drugs, inadequate use of computers, the Internet or mobile phones, and other potential sources of non-substance addiction, sexual and other risk behaviour.

Effective methods and approaches are being sought to adequately solve problems in behaviour. Some methods of intervention are only suitable for certain problems or behavioural disorders, only a certain type of educational environment, or only a certain type of teachers or pupils (e.g. regarding the pupil's age). The choice of strategy needs to be also decided based on the professional competence and practical experience of the teachers, social pedagogue and school psychologist. The social pedagogue as an assisting professional is competent to work with pupils with problem behaviour.

A social pedagogue who is active at a primary of secondary school may provide social counselling to teachers, educators, parents and pupils. In addition to counselling, s/he is competent to provide contacts of other experts in the field of assisting professions. The social pedagogue provides socio-educational counselling to pupils, teachers and parents. Especially beneficial is the counselling of pupils who have a problem. The practising school social pedagogues point to the fact that they are often those who listens to the pupil and in whom the pupil may confide.

The cooperation with experts is another of the fields of their performance - especially when preventing and solving the problem behaviour of the pupils. J. Hroncová (2013, p. 25) says that "prevention of socio-pathological phenomena is a long-term systematic process where a more significant role than until now needs to be played by not only the primary educational institutions, specifically the family and the school, but also institutions of pedagogical counselling and prevention, the police and the public administration".

The development of children is conditioned by family background. It is therefore important to dedicate adequate attention to the cooperation between the school and the family which can be actively fostered by the social pedagogue. The family is a dominant agent of socialization and, as B. Kraus (2015, p. 50) points out, "socialization may take place on various levels, in various quality, so that the influence of adverse and from the perspective of the optimal personal development unfavourable stimuli (or persons), may lead to a state where the resulting behaviour is deviant from the generally accepted standards". Family itself may be the source of adverse stimuli, as well as the source 
of strong protective factors (e.g. strong emotional bond between the parents and the children, clear rules, moderate solicitude, enough time spent with the child, etc.).

Special attention in the field of socio-pedagogical care at school should be paid to the need to attend to the pupils from socially disadvantaged environments and work with them actively. Pupils from socially disadvantaged environments are according to the Education Act pupils living in environments which in view of the social, familial, economic and cultural conditions does not provide enough stimuli for the mental, volitional and emotional qualities of the children or pupils, does not support their socialization and does not provide enough adequate stimuli for the development of their personality. The social pedagogue pays great attention to the socio-educational work with the pupils from socially disadvantaged environments.

The prevention and intervention activities of the workers of assisting professions, i.e. including the social pedagogue, (Gajdošová, Hubinská, \& Jakubková, 2011, p. 7) include:

- improving social atmosphere and climate of the school and bettering the relationships in class groups, as well as relationships between the teachers and the pupils,

- improving social skills of the pupils, conflict solving, management of negative emotions and stress management,

- development of social competences, whether of the workers of assisting professions themselves, or especially the effective problem-solving and conflicts with the children and their parents,

- better familiarization with the personality of the pupil, carrying out adequate socio-pedagogical, special-pedagogical and other diagnostics and choosing intervention strategies for the work with the children,

- securing the psycho-hygiene of learning, upbringing and education,

- effectuating the integration of pupils with special needs to standard schools from a psychological standpoint,

- effectuating prevention and development programs for children and adolescents who are learning to better learn themselves and the others, to communicate adequately, to solve conflicts at school and at home properly, to be tolerant and peaceable, to lower ones aggression and develop assertive behaviour, etc.

According to K. Kropáčová and J. Hroncová (2013, pp. 62-88) socio-educational work of social pedagogues at schools and school facilities focuses on socio-pathological phenomena, socio-pedagogical work with the individual, socio-pedagogical work with groups, socio-pedagogical work with teachers, socio-pedagogical work with the family, socio-pedagogical diagnostics, socio-pedagogical counselling, socio-pedagogical therapy, socio-therapy and socio-pedagogical rehabilitation.

It is possible to positively appreciate the fact that since 2014/2015, social pedagogues have been included in primary and secondary schools as part of the project PRINED (PRoject of INclusive EDucation).

Important for Effective Prevention in the School Environment:

- Professionalization of the implementation of prevention at primary and secondary schools.

- Drawing on an analysis of the occurrence of negative phenomena which need to be prevented (monitoring at schools, intensive work with class teachers, etc.). Predicting the probability of the occurrence of a given phenomenon, or phenomena, and consider the choice of methods and forms of activity, whether in the field of primary or secondary prevention in the school environment.

- Intense attention needs to be paid to the new risks which are brought by modern technologies, 
endangering the pupils of primary and secondary schools: abuse of the mobile phones, of the Internet, cyber-bullying, etc. In connection with the prevention of addictions and other risks of modern technology in pupils of primary and secondary schools, it is necessary:

- First, as teachers, to look for information in professional publications, as well as in the Internet (e.g. www.zodpovedne.sk, etc.).

- Informing the pupils in an age-adequate manner on the risks arising from the use of modern technology.

- Organizing interesting events on the topic, e.g. through an Internet Security Day.

- Teaching the pupils to protect their identity (e.g. in creating their profile or publishing their photos and personal data).

- Emphasizing the danger of personal encounter with people contacted over the Internet.

- Keeping the rule not to continue in a communication with sexual subtext.

- As teachers, assuring the pupils that in case of any of such problems (e.g. cyber-bullying), they may turn to the teachers, or provide the pupils with specialists' contacts.

- Carrying out activities with the pupils on the topic of human rights, children's rights and gender equality, to prevent all forms of discrimination.

- Remembering to prevent victimization. As an example, it is possible to introduce talks at schools, focusing on the increase of caution in the field of work offers abroad in connection with human trafficking, e.g. warn about the techniques of gaining girls to work abroad and the necessity of observing some key rules: not to travel before gaining a work permit, to remember the number of the Slovak Embassy, not to hand over your passport to anybody. Further, it is important to inform the pupils, as of necessity, on the risks of abuse on the labour market, especially during summer holidays, to teach them to recognize job offers which may be hiding some danger, what to ask about during a job mediation, etc.

- Effective prevention should not threaten, ban or command, the rule is to explain, elucidate and offer alternatives.

- It is important to state that the one-time events cannot replace the continual and focused systematic work in the context of primary prevention. A lecture or talk does not have to have a positive effect, as it may even spark the interest in e.g. trying some drugs as a matter of curiosity and experience of danger (talks with abstaining alcoholics or drug addict).

- Use different forms of prevention - e.g. the teaching process, specifically via the courses of ethical education, social studies, etc., special prevention projects and programs, education towards a healthy lifestyle, visual demonstration and the use of ICT tools etc.

- At schools, elaborate conscientious plan of prevention activities and their practical realization.

- Preventive activities must be systematic work implemented at the professional level.

The school is a dominant educational and socializing agent who also plays the important role in the field of prevention - primary and secondary. It is appropriate when schools cooperate on carrying out prevention with professionals, especially with pedagogical-psychological counselling and prevention, as well as with the Police of the Slovak Republic who have specialists of unique training in prevention, also many city or municipal police carry out prevention activities for pupils of primary and secondary schools, even activities suitable for preschools.

In the school environment, it is necessary to consistently solve even minor problems of pupils' behaviour, as with some their neglect or underestimation may lead to more serious forms of deviant 
behaviour. Prevention activity must consist of systematic work carried out throughout the whole school year through the teaching process and apart of it.

The requirement for professionalized prevention processes becomes current nowadays, as various Slovak and European documents point out. In this regard, it is necessary to specifically highlight the work of social pedagogues in schools because they have expertise to carry out primary and secondary prevention, as well as other socially educational work. Their activities at schools are already included in the legislation of the Slovak Republic. It would be beneficial if schools could increase the number of professional staff - social pedagogues, which the current school legislation does enable.

\section{References}

Act no. 245/2008 on Upbringing and Education (the Education Act) and on the Changes and Supplementation of Some Other Acts. [online]. Accessed 19 ${ }^{\text {th }}$ June 2015. https://www.slov-lex.sk/ pravne-predpisy/SK/ZZ/2008/245/20150901.html.

Act no. 317/2009 on Educational, Pedagogical and Professional Staff and on the Changes and Supplementation of Some Other Acts. [online]. Accessed 21 $1^{\text {st }}$ September 2015. https://www. minedu.sk/6826-sk/zakon-c-3172009-z-z-o-pedagogickych-zamestnancoch-a-odbornychzamestnancoch-a-o-zmene-a-doplneni-niektorych-zakonov/.

Bizíková, L. (2011). Výsledky prieskumu Prevencia v praxi ZŠ na Slovensku. [Results of the research Prevention in Practice of Primary Schools in Slovakia]. [online]. Accessed $9^{\text {th }}$ October 2015. http:// www.statpedu.sk/sites/default/files/dokumenty/vyskumne-ulohy-experimentalne-overovania/ prevencia_v_praxi.pdf.

Depistáž 2013 - závery primárnej analýzy. [Screening Test 2013 - Conclusions of the Analysis]. (2014). In Komplexný poradenský systém prevencie a ovplyvňovania sociálnopatologických javov $v$ školskom prostredí. [Complex Counselling System of Prevention and Influence on Socio-Pathological Phenomena in the School Environment]. 5, pp. 81-87. Accessed $13^{\text {th }}$ October 2015. http://www. vudpap-projekt.sk/odborn\%C3\%A9-\%C4\%8Dl\%C3\%A1nky/preview-file/priloha-5-627.pdf.

Gajdošová, E., Hubinská, L., \& Jakubková, V. (2011). Intervencie pracovníkov pomáhajúcich profesií pri riešení problémov a porúch detí v správaní s dôrazom na rozvíjanie ich sociálno-emocionálnej a morálnej zrelosti. [The Interventio of Workers of Assisting Professions in Solving Problems and Disorders of Children in Behaviour with the Emphasis on the Development of Their Socio-Emotional and Moral Maturity]. Bratislava: PROFKREATIS and ÚVZ SR [Public Health Authority of the Slovak Republic].

Hroncová, J. (2013). Prevencia sociálnopatologických javov ako predmet záujmu sociálnej pedagogiky a profesie sociálnych pedagógov v teoretickej reflexii i v praxi. [Prevention of SocioPathological Phenomena as the Subject Matter of Social Pedagogy and of the Vocation of Social Pedagogues in Theoretical Reflection and in Practice]. In Zborník vedeckovýskumných prací Katedry Pedagogiky č. 9 [Collection of Scientific and Research Papers of the Department of Education No 9] (pp. 7-26). Banská Bystrica: PF UMB. 
Komplexný poradenský systém prevencie a ovplyvňovania sociálnopatologických javov $v$ školskom prostredí. [Complex Counselling System of Prevention and Influence on Socio-Pathological Phenomena in the School Environment]. Analýza výsledkov depistáže. [Analysis of the Results of the Screening Test] (2014). [online]. Accessed $6^{\text {th }}$ September 2015. http://www.vudpap-projekt.sk/ odborn\%C3\%A9-\%C4\%8Dl\%C3\%A1nky/preview-file/priloha-5-627.pdf.

Koršňáková, P., Kováčová, J. (2010). Prax učitelov slovenských škôl na nižšom sekundárnom stupni z pohladu medzinárodného výskumu OECD TALIS 2008. [The Practice of the Teachers of Slovak Schools at the Lower Second Stage from the Perspective of International Research OECD Talis 2008]. National Administration. Bratislava: National Institute of Certified Education Measurement.

Kováčová, A. (2015). Činnost' školského sociálneho pedagóga a jeho problémy v základnej škole. [Activity of School Social Pedagogues and Their Problems at Primary School]. In Zborník vedeckovýskumných prací Katedry Pedagogiky č. 111 [Collection of Scientific and Research Papers of the Department of Education No 11] (pp. 37-41). Banská Bystrica: PF UMB.

Kraus, B. et al. (2015). Životní styl současné české rodiny. [The Lifestyle of the Contemporary Czech Family]. Hradec Králové: Gaudeamus.

Kropáčová, K., Hroncová, J. (2013). Sociálno-výchovná práca sociálnych pedagógov v školách a v školských zariadeniach. [Socio-Educational Work of Social Pedagogues in Schools and School Facilities]. In J. Hroncová, I. Emmerová, K. Kropáčová et al., Preventívna sociálno-výchovná činnost' vškole. Metodická príručka pre sociálnych pedagógov a koordinátorov prevencie [The Preventive SocioEducational Activity at School. Methodological Handbook for Social Pedagogues and Prevention Coordinators] (pp. 62-88). Banská Bystrica: PF UMB.

Labáth, V. et al. (2001). Riziková mládež. Možnosti potenciálnych zmien. [Youth at Risk. Possibilities of Potential Change]. Prague: Slon.

Levčíková, M. et al. (2004). Žiak s poruchami správania v základnej a strednej škole. Metodickoinformatívny materiál. [Pupils with Behavioural Disorders at Primary and Secondary Schools. A Methodical-Informational Material]. Bratislava: Štátny pedagogický ústav. [State Institute of Pedagogy].

Miovský, M., Skácelová, L., Zapletalová, J., Novák, P. et al. (2010). Primární prevence rizikového chování ve školství. [Primary Prevention of Risk Behaviour in Education]. Prague: Association SCAN and the Charles University.

Ondrejkovič, P. (2013). Prevencia spoločensky nežiaducich javov. [Prevention of Socially Undesirable Phenomena]. Sociálna prevencia [Social Prevention], 8(1), pp. 11-13.

Pétiová, M. (2015). Šikanovanie v základných a stredných školách. [Bullying in Primary and Secondary Schools]. Bratislava: Centrum vedecko-technických informácií SR.

Pétiová, M. et al. (2014). Pohlad riaditelov základných a stredných škôl na záškoláctvo a predčasné ukončenie povinnej školskej dochádzky. [The Perspective of Primary and Secondary School Directors on Truancy and Premature Termination of Mandatory Attendance]. Bratislava: The Institute School Information and Prognosis. 
Smiková, E. (2012). Efektívna drogová prevencia v školách a školských zariadeniach. [Effective Drug Prevention in Schools and Schooling Facilities]. Bratislava: Methodical-Pedagogical Centre.

Správa o stave bezpečnosti školského prostredia a prevencie negatívnych javov v správaní žiakov $v$ základnej škole v školskom roku 2013/2014. [Report on the State of the Security of the School Environment and of the Prevention of Negative Phenomena in Pupils Behaviour at Primary Schools in the School-Year 2013/2014]. [online]. Accessed $9^{\text {th }}$ October 2015. https://www.ssiba.sk/admin/ fckeditor/editor/userfiles/file/Dokumenty/SPRAVY/121_ZS_UZP_BOZ_13_14_sprava.pdf.

Správa o stave bezpečnosti školského prostredia a prevencie negatívnych javov v správaní žiakov $v$ základnej škole v školskom roku 2012/2013. [Report on the State of the Security of the School Environment and of the Prevention of Negative Phenomena in Pupils Behaviour at Primary Schools in the School-Year 2012/2013]. [online]. Accessed $9^{\text {th }}$ October 2015. https://www.ssiba.sk/admin/ fckeditor/editor/userfiles/file/Dokumenty/SPRAVY/2013/UZP_BOZ_ZS_SR_23.pdf.

Správa o stave školstva na Slovensku a o systémových krokoch na podporu jeho d'alšieho rozvoja. [Report on the State of the School System in the Slovak Republic and on Systemic Steps to Support the Further Development]. Bratislava. [online]. Accessed $8^{\text {th }}$ October 2015. https://www.minedu. sk/sprava-o-stave-skolstva-na-slovensku/.

Vašek, Š. et al. (1995). Špeciálna pedagogika. Terminologický a výkladový slovník. [Special Pedagogy. Terminology and glossary]. Bratislava: SPN.

Zelina, M. (2011). Problémy s problémami v správaní detí a mládeže. [Problems of Problems in Behaviour of Children and the Youth]. Prevence [Prevention], 11(1), pp. 3-9.

\author{
Author \\ prof. PhDr. Ingrid Emmerová, Ph.D. \\ Faculty of Education, Matej Bel University \\ The Department of Pedagogy \\ Ružová 13, 974 11, Banská Bystrica, Slovakia \\ ingrid.emmerova@umb.sk
}

